\title{
睡眠時無呼吸症之循環系変化
}

\author{
一文献的考察一
}

石田達也

\section{Hemodynamics in Sleep Apnea Syndromes}

\author{
-A Review of Literature- \\ Tatsuya Ishida \\ (The University of Tokushima)
}

The literature related to hemodynamics in sleep apnea syndromes was reviewed.

Hemodynamic abnormalities in sleep apnea syndromes include systemic and pulmonary hypertension during wakefulness and sleep and cyclic elevation in arterial pressure with each apneic episode and cardiac arrhythmia. These are thought to play important roles in nocternal sudden death.

Although many aspects of these abnormalities have been studied, cardiovascular, respiratory, endocrine and autonomic nervous system, the mechanism whereby sleep apnea causes abnormalities remains obscure.

There are relatively high incidences of unrecognized sleep apnea in patients with primary hypertension and of untreated sleep apnea causing hypertension.

In summary, further detailed investigation of hemodynamics in sleep apnea is needed, and sleep histories should be clinically required to detect patients requiring therapy for apnea.

Key words: hemodynamics, hypertension, arrhythmia, sleep apnea, sudden death

はじめに

1970年代に入り，睡眠時無呼吸症（sleep apnea；SA）といら概念が確立されるようにな ってから, 睡眠中の呼吸生理に関する研究が盛 んに行なわれるよらになった。 そして睡眠中の 突然死に関する問題が注目されるに従い，高血 圧と肥満の合併が多いとされる SA 症例におい て, 循環系の変化が突然死と深い関わりをもつ のではないかと指摘されるよらになってきた。
循環器科領域からの報告の一つとして, Kurita ら1)の調査(表 1)がある. 彼は, 1975〜 87年までの13年間に, 心臓性突然死を発症した とみなした58例の突然死群と, 年齢, 体重, 身 長, 自衛隊内での階級等をマッチさせた同数の 対照群とを比較検討した. そして, 対照群に比 して, 突然死群の方が, 下記 3 項目の頻度が有 意に高いといら結果を得た。 3 項目とは, (1)収 縮期血圧 $160 \mathrm{mmHg}$ 以上, 拡張期血圧 90 
$\mathrm{mmHg}$ 以上の $\mathrm{WHO}$ 分類 I 期に相当する高血 圧，(2)血清総コレステロール值が $230 \mathrm{mg} / \mathrm{dl}$ 以 上の高コレステロール血症, (3)推定心重量 420 g 以上，である。彼は，突然死を考えるら艺で 高血圧症を無視できないと述べて扣り，この調 查結果からも，高血圧を重要な臨床所見として とらえていく必要がある。

SA に抢ける循環系の変化については，突然 死を防止するらえに扒いて詳細に調査されるべ きものと考无られる。しかし，終夜睡眠検査自 体が検者に負担を与える点や，睡眠を妨げない 循環系機能評価法が発達していないなどの要因 により，実際には研究が進んでいないのが現状 である．また，報告者によって扱った症例や検 查条件に差があるためか，必ずしも同一目的の 調查でも結果が一致しないこともあり，充分な 理解を得られる段階には至っていないと考兄ら れる.

今回著者は，SA に括ける循環系の变化につ いて文献的に検索し，この分野に打ける現状を 把握するとともに，今後の検討課題について言 及することにした．

\section{SA における高血圧の研究経緯}

SA に拈りる循環系の変化に関する研究が行
われ始めたのは，文献的には1970年代と考えら れる。

まず，Tilkian ら2）が，1976年に systemic hypertension（体高血圧）症例を詳しく調査し ている（表 2)。彼は，SA を有する患者12例 を検索し，4 例に覚醒中の体高血圧を認めてお。 り, 睡眠中には 9 例に無呼吸発作毎（無呼吸の 終末頃）の動脈血圧の周期的上昇を認めている. さらに1978年, Guilleminault ら3) が，より大 きな対象群をつくり検索したところ, 閉塞型睡 眠時無呼吸症候群 (obstructive sleep apnea syndrome : OSAS) の52\%に，体高血圧（150/95 $\mathrm{mmHg}$ 以上）を認めている.このようにして $\mathrm{SA}$ と体高血圧との関わりが示唆されるように なった。

Coccagna ${ }^{4)}$ が，1972年に OSAS 患者 5 例の 気管切開術による血圧改善現象を発表したのに 次いで，Burach ら5) が，1976年に OSAS 患者 10例について, 同様の研究（表 3 ）を行ってい る. Burach らは, OSAS 患者の血圧が 157/110 $\mathrm{mmHg}$ (平均) であったにもかかわらず，気管 切開術によって，術後短期間に，正常範囲の 124/74 mmHg（平均）にまで下ったと報告し ている．OSAS 患者では肥満を合併することが

表 1 心臓性突然死群と健常群における発生頻度の比較

\begin{tabular}{l|c|c|c}
\hline \hline & 高血圧症 & 高コレステロール血症 & 心筋重量 $420 \mathrm{~g}$ 以上 \\
\hline 心臓性突然死群 & 16 例 $/ 55$ 例 & 例 $/ 15$ 例 & 18 例 $/ 39$ 例 \\
対照群 & 4 例 $/ 56$ 例 & *例 $/ 32$ 例 & 6 例 $/ 34$ 例一 \\
& $* \mathrm{p}<0.01$ & $* \mathrm{p}<0.05$ & $* \mathrm{p}<0.01$
\end{tabular}

表 2 OSAS 患者12例のカテーテル検査結果

\begin{tabular}{|c|c|c|c|c|}
\hline & \multicolumn{2}{|c|}{ 覚 醒 時 } & 睡 & 眠 \\
\hline & 安静時高血圧 & 運動時高血圧 & 周期的圧上昇 & 〈収縮期圧〉 \\
\hline 大腿動脈圧 & 4例（33\%） & 11例 $(92 \%)$ & 9例 $(75 \%)$ & $\begin{array}{c}3 \text { 例 (25\%) } \\
\langle 200 \mathrm{mmHg} \text { 以上 }\rangle\end{array}$ \\
\hline 肺動脈圧 & 1例（ $8 \% ）$ & 5例 $(42 \%)$ & 10例（83\%） & $\begin{array}{c}5 \text { 例 }(42 \%) \\
\langle 60 \mathrm{mmHg} \text { 以上 }\rangle\end{array}$ \\
\hline
\end{tabular}

睡眠時低酸素血症 $\mathrm{PaO}_{2}<50 \mathrm{mmHg}$ 8例（67\%） 
多く, 肥満が高血圧と関係しているのではない かといら従来の意見に対して, 気道閉塞の解除 のみで血圧が正常化されることを示したことに なる. 肥満の解消を待たずとも, 気道狭窄の解 除にて高血圧も治癒させ得ると判明したことは， 当時としては画期的なことであったと思われる. 続いて Guilleminault ら)は1977年, SA 患者 9 例に対して Swan-Ganz catheter を用いて肺 動脈圧を測定し, 無呼吸発作に伴う肺動脈圧の 上昇を認めている。また Motta ら7) は1978年に， 気管切開術を施行した OSAS 患者 6 例に扣い て, 術前後に大腿動脈および肺動脈の終夜血行 動態モニターを行い（表 4), 術前に比して, 術後両動脈圧の有意な減少を認めている. 彼ら の報告によって, 気道閉塞が, 大循環（収縮期 および拡張期血圧）だけでなく肺循環にも影響 を与えていることが証明されたといえる。

しかし，1980年代に入り，もっと身近に SA を考えさせる報告が Fletcher ら8)によってなさ れている. 彼らは, 中高年層の本態性高血圧症 46例に睡眠ポリグラフを施行し（表 5 ），らち 14例に10を上回る無呼吸指数 (apnea index: AI) を認め, をた正常血圧の対照群34例にも同 様の検査を行い， 3 例に AI > 10 を認めている. さらに高血圧症群で $\mathrm{AI}>10$ であった患者のう ち8 例に, 薬物療法もしくは口蓋垂口蓋咽頭形
成術 (uvulopalatopharyngoplasty ; UPPP) を行 い, 治療後に AI だけでなく収縮期血圧の有意 な減少も認めている.

Williams ら9) は, 高血圧クリニックで降圧療 法を受けている患者23例に睡眠ポリグラフ検査 を施行し，そのうち11例（48\%）に全睡眠時間 の約19\%を占めるほどの，持続時間20秒の SA 発作を認めている.ささらにこの11例のらち 7 例 に, 無呼吸発作中, $\mathrm{SaO}_{2}$ の $4 \%$ 以上の降下も しくは $\mathrm{SaO}_{2}$ 最低值 $90 \%$ 未満の状態を認めてい る. 実に $1 / 3$ の高血圧患者が，SA に起因する 有意な酸素飽和度の低下を示していたことにな る.よって，血圧が正常な者のなかにも SAを

表 5 睡眠時無呼吸症の有無に関する検討

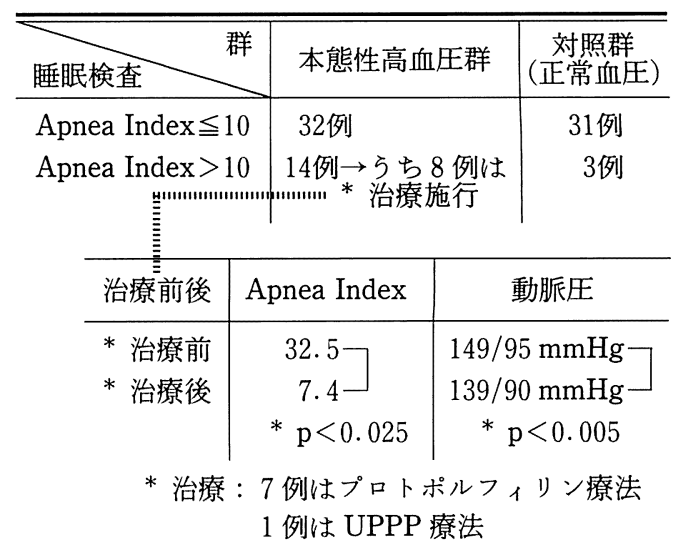

表 3 気管切開術前後（OSAS 患者10例）における動脈圧およびヘマトクリット值

\begin{tabular}{c|c|c|c}
\hline & 動 脈 圧 & Hct & \multicolumn{1}{|c}{ 不整 脈 の 合 併 } \\
\hline 術 前 & $157 / 110 \mathrm{mmHg}$ & $47 \%$ & 8 例 \\
術 後 & $124 / 74 \mathrm{mmHg}$ & $43 \%$ & 8 例中, 4 例は消失 \\
& & & 3 例は著明に減少
\end{tabular}

表 4 気管切開術前後（OSAS 患者 6 例）における動脈圧および動脈血酸素分圧

\begin{tabular}{r|r|r|r}
\hline \hline & 大腿動脈平均圧 & 肺動脈平均圧 & 動脈血 $\mathrm{PO}_{2}$ \\
\hline 術 前 & $137 \pm 6 \mathrm{mmHg}$ \\
術 後 & $97 \pm 3 \mathrm{mmHg}$ & $45 \pm 6 \mathrm{mmHg}$ & $38 \pm 3 \mathrm{mmHg}$ \\
& $* \mathrm{p}<0.005$ & $22 \pm 2 \mathrm{mmHg}$ & $71 \pm 2 \mathrm{mmHg}$ \\
& & $* \mathrm{p}<0.05$ & $* \mathrm{p}<0.001$
\end{tabular}


呈する者もいるし，また高血圧症と診断されて いても SA の存在に気付かない者もいることが 判ってきた．SA の特徵であろらが，SA によ る高血圧が放置されたままになっていることを はじめとして, SA の潜在性は実は多くの問題 を生んでいる可能性がある.

1980年代後半からは, SA を一種の社会問題 として扱ら姿勢が生まれてきており, 疫学的調 查も充実されつつある. また研究施設や研究者 の増加に伴い, 多分野からの報告がなされるよ らになり，現在総合的な知見が得られつつある 段階である.

\section{日中覚醒時の高血圧と夜間低酸素血症}

SA は，一般に夜間睡眠中の異変として受け とめられて拉り, 前述の如く夜間に高血圧を引 き起こすだけでなく，中途覚醒，夜驚，夜尿症， 悪夢などの諸症状をもたらすことが判っている. 一方, 夜間の睡眠呼吸障害が進むと, 日中の傾 眠, 易疲労性, 精神錯乱, 性的機能障害などの 症状が現れるだけでなく, 循環系にまで变化が 及んでくるともいわれている。しかし, 夜間睡 眠中の異常がどのように, 日中の循環系の変化 を生むのかについては，明確にはされていない， 夜間の因子として低酸素血症を, 日中の因子 として高血圧を取り上げ，文献的検索を行って みた。

1. 夜間低酸素血症を左右する因子

$\mathrm{SA}$ では, 夜間睡眠中に, 繰り返す無呼吸発 作によって低酸素血症状態となり, 様々な症状 が出現してくると理解されている. Bradley ら 10) は, OSAS 患者44例に, 動脈血ガス分析, 肺機能検查, 終夜睡眠ポリグラフを行い, 夜間 の動脈血酸素化を規定する因子の調査を行って いる. 結果は, (1)覚醒時 $\mathrm{PaO}_{2}$, 呼気予備能お よび無呼吸時間/睡眠時間比が，夜間の $\mathrm{SaO}_{2}$ と強く相関していた. (2)体重, 他の肺活量およ び呼気流率は, 覚醒時 $\mathrm{PaO}_{2}$ と呼気予備能に影 響を与えていたが，夜間の $\mathrm{SaO}_{2}$ とは関係が認 められなかった, としている. 彼は, 肥満やび まん性気道閉塞などによってよくもたらされる
呼気予備能や覚醒時 $\mathrm{PaO}_{2}$ の異常が, 夜間の低 酸素血症の重症度を規定する重要な因子になる であろらと結論している。

2. 日中の体高血圧

Fletcher ら ${ }^{8)}$ は, 日中の高血圧者のらち AI $>10$ の SA 患者14例の群は, 正常血圧の対照 群より, 睡眠中の酸素飽和度は有意に低下して いたと報告している。また，Williams らの報 告9) においても, 日中の高血圧者の $1 / 3$ に睡眠 中の低酸素血症が証明されている.よって, 夜 間の低酸素血症と日中の高血圧との関係が示唆 されるが，現時点ではそれ以上のことはわかっ ていない.

Fletcher $5^{8)}$ は, 化学受容体を刺激し, 交感 神経の放電を促すような低酸素血症は, 間欠的 にしか起こらないが，無呼吸が頻繁に繰り返さ れると，血圧は睡眠中に基線レベルにまで戻ら なくなるかもしれないと推論している，そして 血圧の上昇が遷延すると, 内分泌変化や神経興 奮が括こり，その結果血管収縮や液貯留現象が 生じるか心拍出量の増加がおこり, 日中の高血 圧になるかもしれないと述べている。

Millman ら ${ }^{11)}$ は, OSAS 患者において，日 中の高血圧を合併させる相対的危険因子につい て調査している。対象症例は, OSAS 患者 206 例であったが，らち92例（45\%）に日中の高血 圧症の合併を認めており，また統計学的処理に よって高血圧の合併は, 年齢と body mass index (BMI) のみ相関していたと述べている.そ こで OSAS 患者 152 例と地理的条件, 人種学的 条件をそろえた対照群904例を選び，さらに年 齢と BMI の条件をマッチさせ，日中の高血圧 の発生を比較してみたところ，下記の群を除く と, 両者間で発生に差異は認めなかったとして いる. すなわち, 25〜44歳の高度肥満 (BMI> $\left.31 \mathrm{Kg} / \mathrm{m}^{2}\right)$ 群では, 対照群に比して日中の高血 圧の有意に高い合併を認めている. 彼は, OSAS に拈ける日中の高血圧の発生は, 主に年齢掞上 び青年〜中年層の高度肥満とに関係しているの であろらと述べている. 
日中の高血圧は，高齢になるに従い他の因子 の影響が加わり， OSAS 群と一般対照群との間 に差が無くなるのかもしれない，今後の検討課 題の一つと考学る.

3 . 日中の肺高血圧

Podszus $5^{12)}$, Weitzenblum $5^{13)}$, 岡田 ${ }^{14)}$ は，OSAS 患者を調査し（表 6 ），覚醒時に肺 高血圧症を認めたのは全体の約 $20 \%$ であと報 告している.Weitzenblum ら ${ }^{13)}$ は, OSAS 患者 46例を日中の肺高血圧合併群 9 例と非合併群37 例に分け，様々な因子の比較（表 7 ）を行って いるが，両群間で，日中 $\mathrm{PaO}_{2}$ 值，日中 $\mathrm{PaCO}_{2}$ 值，VC, $\mathrm{FEV}_{1}$ について有意な差を認めたもの の, $\mathrm{AI}$, 睡眠時 $\mathrm{SaO}_{2}$ 最低值, 無呼吸時間につ いては差を認めていないまた，日中の肺動脈 平均圧值と日中 $\mathrm{PaO}_{2}$ 值, 日中 $\mathrm{PaCO}_{2}$ 値, $\mathrm{FEV}_{1}$ との間に相関関係を認めたのに対し，日 中の肺動脈平均圧值と $\mathrm{AI}$, 睡眠時 $\mathrm{SaO}_{2}$ 最低 值，無呼吸時間との間には相関関係を認めてい ない，彼らは，日中の肺高血圧は，夜間睡眠中 の閉塞型 SA の重症度には関係して拈らず，日 中の低酸素血症の存在と関係していると述べて いる.

他方, 巽ら 15) は, 厚生省呼吸不全調査研究
班の班研究において，SA 患者15例の日中の肺 動脈平均圧値と睡眠時 $\mathrm{SaO}_{2}$ 最低值との間の検 討を行い，負の相関を認めて拉り，岡田ら ${ }^{14)}$ は, 日中の肺高血圧を示す症例の夜間 desaturation は確かに強いのであろうと述べている.

このように現段階では，夜間の低酸素血症が， 日中の肺高血圧に影響を与えているかといら疑 問に対しては，相対する考え方があり結論はつ いていない，今後も検討されるべきであろう．

\section{夜間睡眠時の高血圧}

1 . 体高血圧の原因

睡眠時無呼吸において体高血圧が出現する理 由については，血液成分の変化，レニンーアン ジオテンシン系の作働，交感神経系の関与など が考慮されてきたが，充分な理解が得られるほ どには至っていないのが現状である。

1 ）血液成分の变化

Podszus $5^{12)}$ や Weitzenblum ら ${ }^{13)}$ の報告に みられるように，OSAS 患者に执いては，肺性 心や二次性多血症が認められる場合がある。そ こで，肺水腫や多血症などの変化をもたらすよ らな機序のらち，血液成分の変化に注目して， 高血圧の発症を説明し得ないか検討されてきた.

多血症の発症に関しては, 文献的には,

表 6 OSAS 患者に打ける覚醒時（安静臥位）肺高血圧症頻度

\begin{tabular}{|c|c|c|c|}
\hline = 報 告 者 & $\begin{array}{c}\text { Podszus ら }{ }^{12)} \\
1986 \text { 年 }\end{array}$ & 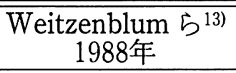 & $\begin{array}{l}\text { 岡田 } 5^{14)} \\
1989 \text { 年 } \\
\end{array}$ \\
\hline OSAS 症例（検討症例数） & 65例 & 46例 & 11例 \\
\hline OSAS 症例（肺高血圧例*） & 13例 $(20 \%)$ & 9 例 $(20 \%)$ & 2例（19\%） \\
\hline
\end{tabular}

表 7 OSAS 患者に括ける日中肺高血圧合併群と非合併群の各因子の比較

\begin{tabular}{|c|c|c|c|}
\hline = 総数46例 & $\begin{array}{c}\text { 肺高血圧群 } \\
9 \text { 例 }\end{array}$ & $\begin{array}{c}\text { 非肺高血圧群 } \\
37 \text { 例 } \\
\end{array}$ & \\
\hline $\begin{array}{l}\text { 昼間の } \mathrm{PaO}_{2} \text { 值 } \\
\text { 昼間の } \mathrm{PaCO}_{2} \text { 值 } \\
\mathrm{VC} \mathrm{FEV}_{1} \text { の值 }\end{array}$ & $\begin{array}{l}60.8 \pm 7.6 \mathrm{mmHg} \\
44.6 \pm 4.2 \mathrm{mmHg}\end{array}$ & $\begin{array}{l}76.2 \pm 9.4 \mathrm{mmHg} \\
38.2 \pm 4.0 \mathrm{mmHg}\end{array}$ & $\begin{array}{l}\mathrm{P}<0.001 \\
\mathrm{P}<0.001 \\
\mathrm{P}<0.001\end{array}$ \\
\hline $\begin{array}{l}\mathrm{AI} \\
\text { 睡眠時 } \mathrm{SaO}_{2} \text { 最低值 } \\
\text { 無呼吸時間 }\end{array}$ & $\begin{array}{l}62 \pm 34 \\
59 \pm 21 \%\end{array}$ & $\begin{array}{l}65 \pm 40 \\
66 \pm 18 \%\end{array}$ & $\begin{array}{l}\text { ns } \\
\text { ns } \\
\text { ns }\end{array}$ \\
\hline
\end{tabular}


Guilleminault ら16) の唱えた機序が，最近むで 支持されてきたといえる，すなわち，OSAS に 扣いては，睡眠中のガス交換障害に起因する長 期の低酸素血症があり，二次的に多血症となる という考え方である。

しかし，Krieger ら 17）の1990年の報告（表 8 ） でこの考光方にやや疑問がもたれるようになっ てきた. Krieger らは, OSAS 患者 8 例に nasal CPAP 療法を一晚行っただけで, Hb, Hct，尿量 の有意な低下が得られたと述べており，Guilleminault が唱光た機序のみでは，この短時間での 血液成分の变化は説明し得ないと意見している. Krieger は，この血液所見の変化を，心房性ナ トリウム利尿ペプチド (atrial natriuretic pep-

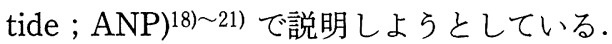

ANP は，心房だけでなく，脳，心室などい くつかの組織で作られるペプチドである。しか し，血中に放出され生理的活性を示すのは汪と んどが心房由来の ANP とされている．作用と しては,

1）腎臓での $\mathrm{Na}$ 排泄を増加させる働き

2 ）血管内から血管外へ液体をシフトさせる 働き

3 ）血管を拡張させる働き

4) アルドステロンをはじめレニンーアンジ オテンシン系，抗利尿ホルモン，カテ コラミンなどの分泌を抑制する働き などがある。

Krieger らは, 別の論文で, OSAS 患者では ANP の放出が方進しているとも報告22) してお り，これに前述の一晚の nasal CPAP 療法によ る血液成分の改善結果 ${ }^{17)}$ をつけ加光，以下の 如く推論している. 寸なわち, (1)OSAS 患者で
は ANP 分泌元進によって腎臓での利尿が促進 され，また血管内から血管外への水分移動が起 こり血液の濃縮現象が起こっている, (2)nasal CPAP 療法が施行されると, ANP 分泌が抑制 され，その結果血液の希釈現象が扣こり，臨床 上, $\mathrm{Hb}$ と Hct の有意な低下としてとらえられ る，といら考方方である。

赤柴ら 23) も，赤血球寿命を考えれば，一晚 の nasal CPAP 治療が低酸素血症を改善し多血 症を消失せしめるとは考兄難く, Hb や Hct の 低下の機序は, やはり水分の移動による赤血球 容積の増大を考える方が妥当であろうと述べて いる.

羽田ら ${ }^{24)}$ は, 高血圧を伴う OSAS 患者に nasal CPAP 療法を施行し, 3 週後に血圧の改 善と血液粘稠度の減少が認められたと報告して いる.ここで Krieger らや赤柴らの考方であ る水分移動に伴ら血液の濃縮現象が nasal CPAP 療法の施行前に在ったとすると，血液粘 稠度が高かったといら現象の理由付けは容易と なってくる。また血液粘稠度の亢進によって， 持続的な高血圧が生まれている可能性も想定で きると考兄られる。

一方, 平田 ${ }^{19)}$, 中川 ${ }^{20)}$, 中村 $5^{21)}$ の解説飞 よれば, 当初, ANP は高血圧症患者で増加し ていたため，その作用不足で高血圧が発生して くると考えられたこともあったが，実際には高 血圧に伴われた二次的な代償機構（血圧上昇抑 制機構）の一つとして ANP をとらえるべきで あるとしている．この見解に従えば，OSAS 患 者に扣いて ANP 值が増加しているといら事実 は，OSAS で高血圧状態が基盤に成立している 症例が多いことを示しており，循環系の変化を

表 8 nasal CPAP 療法施行（一晚）前後の血液および尿所見

\begin{tabular}{c|c|c|c}
\hline \hline & Hct 值 & $\begin{array}{c}\text { RBC 数 } \\
\left(\times 10^{6} / \mathrm{mm}^{3}\right)\end{array}$ & 尿 量 \\
\hline 施行前 & $45.6 \pm 1.27$ & $4.777 \pm 0.168$ & $61.2 \pm 10.9$ \\
施行後 & $43.0 \pm 1.4-$ & $4.577 \pm 0.174$ & $31.4 \pm 3.5$ \\
& $* \mathrm{p}<0.0005$ & $* \mathrm{p}<0.0005$ & $* \mathrm{p}<0.025$
\end{tabular}


より詳細に検討していくことの重要性が示唆さ れてくる.

以上，血液成分の变化と持続的な高血圧とは， 何らかの関連性があるとはいえるが，詳細につ いては未だ不明であり，さらに研究が必要であ るといえる。また，無呼吸発作毎に認められる 一過性血圧変動に関しては，血液成分の変化だ けで説明することは不可能であり，異なった機 構が存在するものと考学られる.

\section{2 ) 交感神経系の活動性}

Hedner ら 25) は，SA 患者に打ける交感神経 活動の関わりを確認すべく，腓骨神経束にタン グステン電極を刺入し，遠心性神経節後性の交 感神経筋活動を記録している．対象は，SA 患 者 6 例と，性，年齢を適合させた対照群 6 例と した。その結果，(1)覚醒中（表 9）扣よび SA 発作期以外の睡眠中では，交感神経活動は，対 照例に比して SA 患者の方がより高い状態にあ った，(2)SA 患者の SA 発作期では，交感神経 活動は，無呼吸に先行して突然低下し，その後 は再上昇し高く維持されて扣り，血圧や心拍数 は，やや遅れて，無呼吸に引き続く換気再開相 で，低下から上昇に転じる周期性の変化を呈し ていた.よって，この研究により，SA患者で は，交感神経活動は夜間・日中を問わず常に高 まった状態にあり，また無呼吸発作期には，反 復性に一過性低下し，それに同期し循環系の変 化が認められることが判ってきた.

交感神経の活動をノルアドレナリン (NA) で みた研究もある。血中 NA 濃度は交感神経系 の活動に伴って変動するため, 交感神経系の活

表 9 積分処理した覚醒時安静仰臥位 (muscle nerve sympathetic activity; MSA)

\begin{tabular}{c|c|c|c}
\hline & 人数 & 高血圧合併 & MSA \\
\hline SA群 & 6 例 & 4 例 & $75.3 \pm 12.76$ \\
対照群 & 6 例 & - & $35.9 \pm 3.76$ \\
& & & $* \mathrm{p}<0.05$
\end{tabular}

$\mathrm{SA}$ 群の症例と年齢・性を適合させた症例を対照 群として選んでいる.
動レベルを計る指標として血中 NA 濃度がよ く用いられている。また血中に放出された NA のほとんどは，10２0分間に尿中に排泄され る26) ため, 同じく尿中 NA 濃度も交感神経系 の活動レベルとしてょく用いられる．

田代ら ${ }^{27)}$ は, SA 患者15例と非 SA 患者 6 例 を対象として，SA に拈ける交感神経系の活動 について調査している. 彼らは，24時間にわた って尿中 NA 排泄量を測定し, SA 群に抢いて は, 夜間睡眠中の尿中 NA 排泄量が, 覚醒時 のどの時間帯の NA 排泄量よりも高く, 逆に 対照群に拈いては, 夜間睡眠中の尿中 NA 排 泄量が，覚醒時のどの時間帯の NA 排泄量よ りも低かったと報告している。また，SA 群に 拈いて，夜間睡眠中の尿中 NA 排泄量と $\mathrm{AI}$ の 関係を検討し，有意な相関を認めたとしている. その結果, 交感神経系の活動は健康成人では一 日のらち夜間睡眠中に最も低下しているが， SA 患者では全く逆に, 夜間睡眠中に最も六進 して拈り，また交感神経系の活動六進の度合い は, 夜間睡眠中の無呼吸の程度に応じて高まる と結論している。

田代ら ${ }^{27)}$ は, 次に SA 患者のうち高血圧を合 併している 2 例に UPPP もしくは気管癭孔形 成術を施行し, 術前後の AI, 血圧と心拍数, 尿中 NA 排泄量を比較検討している. その結 果, 手術によって無呼吸は改善し, 血圧, 心拍 数が夜間睡眠中だけでなく日中覚醒時にも有意 な低下を示し, かつ血圧, 心拍数の日内变動に 関しても夜間睡眠中に最低値を示す正常パター ンになったとしている，尿中 NA 排泄量に関 しても, 術前には, 一日のらちで夜間睡眠中に 最も高值をとったのに対して，術後には，夜間 睡眠中に最も低值をとって括り，前述の非 SA 患者にみられたパターンと同じになったと報告 している.この結果, SA 患者に执いては, 夜 間睡眠中に交感神経系の異常な活動立進がおこ って拈り，重症例に拈いてはこの活動六進が高 血圧症の発症を促していると推測している.

以上, 現段階では, 交感神経の活動性が血圧 
と深く関係していると受けとめられているが， 逆に交感神経活動の変化のみですべての現象が 説明し得るのかといら疑問に対しては，今後も 検討されなくてはならないであろう。また交感 神経活動は個々人の間で差が大きいため, 個人 間で比較するには問題があり，研究を行う際の 条件設定にはよほど慎重でなければならないと 考光られる。

3 ）内分泌系の変化

田代ら 27) は, 前述の一連の研究のなかで, NA 以外飞昇圧作用を有するホルモンとして, アドレナリン，ドパミン，セロトニン，レニン， アルドステロン，コルチゾール等を調査してい る. 彼らは, 朝覚醒直後に SA 患者から採血し, これらのホルモン值を測定してみたが， $\mathrm{AI}$ と の間に相関が得られたのは NA のみであった と述べている.よって彼らは，血圧に対して NA 以外の内分泌系の関与は否定的であろうと 結論している.

また Follenius ら ${ }^{28)}$ は，7例の OSAS 男性患 者に nasal CPAP 療法を行い，その前後での血 漿レニンとアルドステロンの動きを検討してい る. その結果, 治療前に比して, 治療後に徐波 睡眠の増加と, 血漿レンン值およびアルドステ ロン值の有意な上昇を認めている。また血漿レ ニン值の経時的変動曲線は, 治療前には, 終夜 にわたり平坦であったが，治療後には，睡眠構 築の回復に従って, 正常者と同様の睡眠周期に 伴った变動を示すようになり，その結果アルド
ステロンの変動曲線も正常化したと述べている. よって, 治療後にレニンやアルドステロン值が 上昇したといら事実からみて, nasal CPAP 療 法による血圧の下降正常化現象は，このシステ ムでは説明がつかないと考えられる。

以上, SA に括いて, 内分泌学的には, 高血 圧をもたらす㴗どの機序はつきとめられていな いとい觉る。しかし，血圧が変動したことによ って，どのような内分泌学的反応が出現してい るかといら点に関しては未だ研究されて拈らず, 今後の研究課題となるかもしれない.

4 ）降圧剤からみた高血圧

Mayer ら 29) は，高血圧を合併する12例の OSAS 患者に, angiotensin converting enzyme (ACE) 阻害剂であるシラザプリルンを投与し, $\mathrm{AI}$ と血圧の有意な低下が得られたと報告して いる（表10）。彼は，呼吸中枢系と血圧制御と の間のフィードバック機構を想定し，血圧を下 げることによって，呼吸制御機構に促進的な効 果を生むのではないかと推定している. ACE 阻害剂は降圧剤の一種であり, 今後この現象を 説明すべく，様々な降圧剤を用いた臨床研究が 行われる可能性があると考えられる. Mayer は, この現象は，降圧剤の非特異的効果である かもしれないと指摘する一方，呼吸中枢に対す る直接作用を有するような降圧剤では，逆に無 呼吸を促進するかもしれないので，臨床研究に は注意を要すると警告している。

無呼吸に対する治療によって高血圧が改善さ

表10 高血圧を合併する OSAS 患者12例に対するシラザプリル（ACE 阻害剤）投与 前後の比較

\begin{tabular}{|c|c|c|}
\hline & 投 薬 前 & 投 薬 \\
\hline 収縮期血圧（mmHg） & $155(130 \sim 210)$ & $133^{* *}(112 \sim 163)$ \\
\hline 拡張期血圧（mmHg） & $102(95 \sim 108)$ & $82^{* *}(60 \sim 100)$ \\
\hline 心拍数（beats/分） & $78(66 \sim 106)$ & $(57 \sim 102)$ \\
\hline 総睡眠時間（分） & $368(295 \sim 424)$ & $(265 \sim 434)$ \\
\hline REM 睡眠（\%） & $19(10 \sim 32)$ & $(10 \sim 29)$ \\
\hline AI & $40(12 \sim 84)$ & 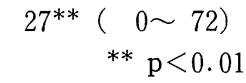 \\
\hline
\end{tabular}


れる事実と，血圧を下げる薬物療法によって， 血圧だけでなく無呼吸も改善される事実とを結 び付ける機構を解明していくことが，今後の研 究課題のひとつと考兄られる.

\section{2 . 肺高血圧の原因}

Podszus ら ${ }^{15)}$ によと，11例の SA 患者に睡 眠ポリグラフを施行し，無呼吸に伴う肺動脈圧 の上昇を認めたが，特に約半数の 6 例に掞いて は睡眠中にのみ平均肺動脈圧が $22 \mathrm{mmHg}$ を上 回る異常な上昇を示したと報告している.この ように覚醒時に肺高血圧が無いような症例にお いても，睡眠中の肺高血圧症は起こり得ること が判ってきている.

肺高血圧症の発症機序について, 国枝30) は, 低酸素性肺血管収縮 (hypoxic pulmonary vasoconstriction ; HPV) 現象を用いて解説してい る.この現象は, 肺胞領域の低酸素症 (alveolar hypoxia) によって, 該当領域の肺血管が収縮 することをいい，肺局所でも全肺でも拈こると されている，しかし，低酸素血症 (hypoxemia) で起こるのではなく, 例えば肺胞低酸素症の結 果として，低酸素血症が出現した場合には HPV がみられるが，他の原因による低酸素血 症では, HPVはみられないとされている. SA での肺高血圧の機序は, (1)有効肺胞換気量の低 下によって, 肺胞低酸素症が起こる, (2) 奔の結 果, HPV 現象が拈こり肺血管抵抗が増加し肺 高血圧状態となる，というものである.

一方，岡田ら ${ }^{14)}$ は OSAS 患者を詳細倜査 検討したところ，20３0秒程度の比較的短い閉 塞型 SA 発作では, 心拍数, 体血圧, 肺動脈血 圧の低下がみられ，それは呼吸再開とともに一
過性上昇を示したが，30秒を越光る比較的長い 閉塞型 SA 発作では，初期に低下していた肺動 脈血圧は徐々に上昇し, 無呼吸前よりも上昇し ていたとしている。この結果について，岡田ら は, 短い無呼吸時には, 胸腔内陰圧が徐々に進 行するため，みかけ上，肺動脈圧はわずかに低 下し，呼吸再開期に一過性上昇する状態にある と解説している. 他方, 長い無呼吸中にみられ た肺動脈圧上昇時点での血液ガス分析結果で, 著明な低酸素症掞よび呼吸性アシドーシス状況 にあると判明したことから，無呼吸が長く続く と HPV 現象が起こり，その結果肺動脈圧は無 呼吸前より高い状態となるのだろうと述べてい る.

\section{3. 右心不全}

Bradley ら ${ }^{31)}$ は, 統計学的検討を行い(表11), OSAS 患者で右心不全を合併する者は，非合併 例に比して, 夜間睡眠中の $\mathrm{SaO}_{2}$ がより低く, 覚醒時においても $\mathrm{PaO}_{2}$ がより低く $\mathrm{PaCO}_{2}$ が より高いという結果を得たため, 右心不全に至 る過程には，昼夜にわたる低酸素血症と高炭酸 ガス症が深くかかわって扣り，びまん性の気道 閉塞が低酸素血症を生む要因となっているであ ろらと想定している. Bradley ら ${ }^{32)}$ は，さらに 高炭酸ガス症の成立機序について研究（表12） を行って扣り，OSAS 50例を高炭酸ガス群 7 例 と正常炭酸ガス群43例に分け比較している。そ して高炭酸がス群の方が，有意に肥満度が高い といら結果を得たため，体重適合による肥満者 同士の組み合わせを作成し再検討を行ったとこ ろ, 両群の間で AI や無呼吸の持続時間には差 は認めなかったとしている。をた， $\mathrm{PaCO}_{2}$ と

表11 OSAS 患者に拉ける右心不全合併の有無による比較

\begin{tabular}{|c|c|c|c|}
\hline OSAS50例 & $\begin{array}{c}\text { 右心不全合併例 } \\
6 \text { 例 }\end{array}$ & $\begin{array}{c}\text { 合併なし } \\
\text { 44例 }\end{array}$ & \\
\hline $\mathrm{AI}$ & $30 \pm 10$ & $33 \pm 4$ & ns \\
\hline 平均夜間 : $\mathrm{SaO}_{2}$ & $76 \pm 3 \%$ & $90 \pm 1 \%$ & $\mathrm{p}<0.001$ \\
\hline 覚醒時: $\mathrm{PaO}_{2}$ & $52 \pm 4 \mathrm{mmHg}<$ & $75 \pm 2 \mathrm{mmHg}$ & $\mathrm{p}<0.001$ \\
\hline 覚醒時 : $\mathrm{PaCO}_{2}$ & $51 \pm 2 \mathrm{mmHg}>$ & $36 \pm 1 \mathrm{mmHg}$ & $\mathrm{p}<0.001$ \\
\hline
\end{tabular}


様々な因子との相関を検討しており, 気道力学 に影響を受けるような呼気予備量と $\mathrm{FEV}_{1}$ /FVCのみが， $\mathrm{PaCO}_{2}$ と相関していたとしてい る.そのため, 肥満者であっても, OSASだけ で覚醒時高炭酸ガス症が生まれるのではなく， 慢性的な炭酸ガス貯留への進展にはやはりびま ん性の気道閉塞が背景にあるのではないかと想 定している.

\section{睡眠時無呼吸症之胸郭内陰圧}

閉塞型 SA では，気道閉塞に逆らって吸気を 行うことにより，その結果胸郭内に陰圧が生じ ることが分かって拉り, 日常臨床で閉塞度の指 標として, 咽頭内圧 ${ }^{3334)}$ や食道内圧 ${ }^{35}$ 36) の測定 法が採用されるに至っている。

文献的には，Tolle $5^{37)}$ が1983年，閉塞型 OSAS 患者10例に対して, 一回拍出量測定（非 侵襲的電気的インピーダンス法）を行い，覚醒 時に比して閉塞型睡眠時無呼吸時には, 一回拍 出量は有意に減少したと報告している。彼は, 胸郭内圧（食道バルーン法）測定を睡眠ポリグ ラフ検查に加之, 一回拍出量の減少と拡張期胸 郭内圧值との間に有意な相関が得られたことか ら, 心室の負荷が, 胸郭内圧変動によって影響 を受けていると結論するに至っている.

また, Ringler ら ${ }^{38)}$ は1990年, OSAS 患者 6 例に対して, 無呼吸発作期に酸素吸入（表13） を行い, $\mathrm{SaO}_{2}$ 值が改善されたにもかかわらず,
換気再開期の動脈血圧上昇現象は継続していた ことから，換気再開期の血圧上昇は，動脈血低 酸素血症のみによっておこる現象ではないと結 論している. 彼らは，これに対して胸郭内圧の 変化などの他の因子の存在を想定している.

著者ら ${ }^{39)}$ は, OSAS 患者 3 例について, 咽 頭内圧と指尖部動脈血圧（非観血的圧測定法） との同時測定を行い，換気再開期の動脈圧上昇 を3例ともに認めたのに対して，無呼吸相終末 では, 咽頭内陰圧の重度の例では動脈圧一過性 下降現象を認めたものの, 軽度の症例では認め なかった。この事実からも，胸郭内陰圧の程度 によっても循環系の変化に差が生じるものと推 定される.

循環系に拈ける变化を調査していくら劣では， 胸郭内圧の評価も不可欠であると結論される.

\section{睡眠時無呼吸症と不整脈}

SA 患者に拈ける不整脈の頻度について， Tilkian 5 ${ }^{40)}$, Miller ${ }^{41)}$, Guilleminault $5^{42)}$, Shepard ら ${ }^{43)}$ が報告している（表14）.

表13 睡眠時無呼吸期の酸素供給と平均動脈血圧 の変化

\begin{tabular}{c|c|c}
\hline \hline & $\begin{array}{c}\text { lowest } \mathrm{SaO} 2 \\
\%\end{array}$ & $\begin{array}{c}\text { 平均動脈血圧変化 } \\
\text { (平均值) } \mathrm{mmHg}\end{array}$ \\
\hline 酸素供給前 & $79 \sim 82$ & $21.3 \pm 9.2$ \\
酸素供給後 & $93.6 \pm 2.4$ & $18.8 \pm 7.1$
\end{tabular}

表12 OSAS 患者50例に打ける覚醒時高炭酸ガス症の有無による比較

\begin{tabular}{l|ccc}
\hline \hline & 高炭酸ガス群 & 正常炭酸ガス群 & \\
覚醒時 : $\mathrm{PaCO}_{2}(\mathrm{mmHg})$ & $51 \pm 2$ & $35 \pm 1$ & \\
OSAS 50例 & 7 例 & 43 例 & \\
\hline 理想体重との比 & $181 \pm 11 \%>$ & $148 \pm 6 \%$ & $\mathrm{p}<0.005$ \\
\hline \multicolumn{4}{l}{} \\
\hline
\end{tabular}


閉塞型 SA でみられる心臓の調律障害では, 洞性不整脈が最もよくみられるもので, Guilleminault ら ${ }^{42)}$ は, OSAS 患者400例の検索で, 全 症例の78\%に認めたとしている. 彼は，閉塞型 SA に打ける致死的な不整脈として洞停止や洞 性徐脈をあげている. Tilkian ら40) は, OSAS 患者の徐脈性不整脈については，アトロピンで 改善されたと報告して扣り，迷走神経の遠心路 が強く働いていることが示唆されている.

一方, Bayes de Luna 544) は，ホルター心電 図記録中突然死した症例を文献的に集計し (表15), 総数 157 例について, 死亡直前の心電 図を検討している.SA を中心に集めたデータ ではないため，異なった視点での評価がなされ ている. 彼らは, 突然死の直接原因は, 頻拍型 心室性不整脈が $83.4 \%$ 占め, 徐脈性不整脈に よるものは $16.5 \%$ にすきなかったと報告してい る. 具体的には，心室頻拍症から心室細動を経 て，あるいは心室性頻拍症から直接死に至った 者が，最多であると述べている．田辺45) は， 比較的心状態の安定期に発生した心室期外収縮 は，たとえ基礎疾患があっても突然死の頻度は それほど高いものではないが，もともと心室頻 拍，心機能低下，心筋虚血発作などが合併して いる場合には，心室不整脈が独立因子として， あるいは心機能低下や心筋虚血発作と関連して 突然死と結びつきやすいと解説している。この ように突然死症例から検索したデータでは，心
室性不整脈が重要であると考えられている.

Tilkian 5 40) は，SA の睡眠中と覚醒時にお。 ける不整脈出現を比較検討しており，覚醒時に は心室性期外収縮のみが認められたのに対して， 睡眠中には様々な型の不整脈が認められ，かつ 心室性期外収縮の症例数が増加したと報告して いる. Miller ら ${ }^{41)}$ は, SA の心室性異所性不整 脈について検討しており, 睡眠中と覚醒中とで は, 出現頻度に差がなかったと述べているのに 対して，更に大きな集団で検索した Guilleminault ら 42) は, OSAS 患者400例のらち55例 （14\%）に拈いて，睡眠時における方が心室性 不整脈が増加したと述べている，報告者によっ て対象症例の重症度が異なって扣り, 結果に違 いが生じるのであろらが，多数症例の検討結果 に重点をおけば，睡眠中に不整脈が増加すると 考えられる.この点, 昼間の外来診療のみで OSAS 患者の不整脈を評価することは不十分と

表15 ホルター心電図記録中突然死を生じた157 例に括ける死亡直前の解析所見

\begin{tabular}{c|c}
\hline \hline 不整脈分類 & 例 数 \\
\hline 頻拍型心室性不整脈 & 131例（83.5\%) \\
(1)心室頻拍症 & 98 例 $(62.4 \%)$ \\
(2)Torsades de pointes & 20 例 $(12.7 \%)$ \\
(3)原発性心室細動 & 13 例（ $8.3 \%)$ \\
\hline 徐脈性不整脈 & 26例 $(16.5 \%)$
\end{tabular}

表14 睡眠時無呼吸症状の不整脈の出現頻度

\begin{tabular}{|c|c|c|c|c|}
\hline 報告者 & $\begin{array}{c}\text { Tilkian }^{40)} \\
\text { 1977年 } \\
\end{array}$ & $\begin{array}{c}\text { Miller }^{41)} \\
\text { 1982年 }\end{array}$ & $\begin{array}{c}\text { Guilleminault } \\
\text { 1983年 }\end{array}$ & $\begin{array}{c}\text { Shepard 5 } \\
\text { 1985 } \\
\end{array}$ \\
\hline 検 索 数 & 15例 & 23例 & 400例 & 31例 \\
\hline 洞性不整脈 & $93 \%$ & - & $78 \%$ & - \\
\hline 洞性除脈（30回／分以下） & $40 \%$ & $9 \%$ & $7 \%$ & $10 \%$ \\
\hline 洞性休止（2 13秒） & $33 \%$ & $9 \%$ & $11 \%$ & $10 \%$ \\
\hline II ${ }^{\circ}$ 房室ブロック & $13 \%$ & $4 \%$ & $8 \%$ & $6 \%$ \\
\hline 心室性異所性不整脈 & $67 \%$ & $57 \%$ & $19 \%$ & $74 \%$ \\
\hline 副調律 & & $9 \%$ & - & $55 \%$ \\
\hline 心室性頻脈 & $13 \%$ & $0 \%$ & $2 \%$ & $3 \%$ \\
\hline
\end{tabular}


考えられ, 睡眠検査の重要性が再確認される.

Shepard ら ${ }^{43)}$ は，睡眠中のオキシへモグロ ビン不飽和度と心室性異所性不整脈出現との関 係を検討し， $\mathrm{SaO}_{2}$ が $60 \%$ 以上では心室性期外 収縮出現は比較的少ないが，60\%を下回ると出 現は有意に増加したと報告している．彼らは， $\mathrm{SaO}_{2}$ が60\%をわる場合には，不整脈を防止す る目的で呼吸管理が必要であるといら意見を述 ベている，野田ら ${ }^{46)}$ は, OSAS 患者31例につ いて，無呼吸開始御10秒間と換気再開後 10 秒間 の心拍数を比較し，心拍数が変動する群の方が, 変動しなかった群に比して, 無呼吸中の lowest $\mathrm{SaO}_{2}$ は低く, $\mathrm{SaO}_{2} 90 \%$ 以下の総持続時間が延 長していたと報告している。 また変動を示した 群の典型例において, 心拍数変動の程度と lowest $\mathrm{SaO}_{2}$ との間に負の相関関係を認めたとも述べ ている。また，Zwillich ら47)は，OSAS 患者の 検討で，無呼吸中の徐脈の程度は，無呼吸の持 続時間と $\mathrm{SaO}_{2}$ 低下の程度と有意に相関してい たと報告している。よって無呼吸に伴ら低酸素 血症と心拍リズム異常との間には何らかの関係 があることが示唆される。

Guilleminault $ら^{42)}$ も不整脈発生には低酸素 血症が重要な因子となっていると述べているが, 彼らはさらに，閉塞型 SA における交感神経活 動性の交進に着目しており，この自律神経機能 のバランスの崩れが心臓の刺激伝導系の異常を もたらす因子となっているのであろらと述べて いる.

以上，不整脈が， SA と突然死との関係に沶 いて大きな位置をしめていることは確かである が，SA に打壮不整脈の発生機序に関する検 討は未だ充分にされては打らず，今後の研究課 題の一つと考えられる.

\section{まとめ}

睡眠時無呼吸症における循環系変化について 文献検索を行い, 次のような結果を得た。

1) 睡眠時無呼吸症による高血圧症が気づか れずに末治療のまま放置されている場合がある。

2 ）日中覚醒時や夜間睡眠時にみられる持続
的血圧上昇ならびに無呼吸発作時にみられる一 過性の血圧変動の発生機構は, 呼吸生理学的, 循環器学的, 自律神経学的, 内分泌学的な立場 で研究されているが，未だ充分に解明されてい ない.

3）睡眠時無呼吸症に打ける不整脈は，突然 死への進展過程に沶いて大きな役割を占めてい ると考えられているが，その発生機構は未だ充 分に解明されていない.

よって，睡眠時無呼吸症の潜在性により注意 を払らことが臨床上重要であり，また突然死を 予防すべく循環系変化の発生機構の解明をめざ すことが必要であると考えられた。

稿を終えるにあたり，御校閲を賜った徳島大学医 学部耳鼻咽喉科学教室小池靖夫教授に深謝致します.

\section{参考文献}

1) Kurita A, Uehata A, Nishioka $T$, et al : An investigation of sudden cardiac death in apparently healthy young men by annual health examination. Jpn J Hygiene 44 : 739 747, 1989.

2) Tilkian AG, Guillemiault $C$, Schroeder, et al : Hemodynamics in sleep-induced apnea; studies during wakefulness and sleep. Ann Int Med 85 : 714 719, 1976.

3) Guilleminault C, Van Den Hoed J and Miller MM : Clinical overview of the sleep apnea syndromes. Sleep apena syndromes (ed by Guilleminault C and Dement WC). pp 1 12, Alan R Liss Inc, New York, 1978.

4) Coccagna G, Mantovani M, Brignani F, et al : Tracheostomy in hypersomnia with periodic breathing. Bull Physiopathol Respir 8 : 1217 $\sim 1227,1972$.

5) Burach B, Pollak C, Borowiecki B, et al : The hypersomnia-sleep apnea syndrome (HSA) ; a reversible major cardiovascular hazard. Circulation 56 : III 177, 1977.

6) Guilleminault C, Eldridge FL and Dement WC : Human pathology sleep-induced apneas and cardio-vascular changes. Bull Physiopathol Respir $10: 244 \sim 247,1977$.

7) Motta J, Guilleminault C, Schroeder JS, et al : 
Tracheostomy and hemodynamic changes in sleep-induced apnea. Ann Int Med 89 : 454 458, 1978.

8) Fletcher EC, DeBehnke RD, Lovoi MS, et al : Undiagnosed sleep apnea in patients with essential hypertension. Ann Int Med $103: 190 \sim 195$, 1985.

9) Williams AJ, Houston D, Finberg S, et al : Sleep apnea syndrome and essential hypertension. Am J Cardiol 55 : 1019 1022, 1985.

10) Bradley $T D$, Martinez $D$, Rutherford $R$, et al : Physiological determinants of nocturnal arterial oxygenation in patients with obstructive sleep apnea. J Appl Physiol 59 : 1364 1368, 1985.

11) Millman RP, Redline S, Carlisle CC, et al : Daytime hypertension in obstructive sleep apnea. Chest $99: 861 \sim 866,1991$.

12) Podszus T, Bauer J, Mayer J, et al : Sleep apnea and pulmonary hypertension. Klin Wochenschr $64: 131 \sim 134,1986$.

13) Weitzenblum E, Krieger J, Apprill M, et al : Daytime pulmonary hypertension in patients with obstructive sleep apnea syndrome. Am Rev Respir Dis 138 : 345 349, 1988.

14）岡田 修, 篠崎俊秀, 栗山喬之: 睡眠時無呼吸 症候群における循環障害. 日気食会報 $40: 403$ $\sim 408,1989$.

15）巽浩一郎, 佐久間哲也, 星野 隆, 他: 在宅酸 素療法の適応基準に関する検討一特に睡眠時 の低酸素血症からの検討一. 厚生省特定疾患. 呼吸不全調查研究班昭和 63 年度研究報告書. 102 108頁, 1989.

16) Guilleminault $C$, Tilkian A and Dement WC : The sleep apnea syndromes. Annu Rev Med $27:$ 465 484, 1976.

17) Krieger J, Sforza E, Barthelmebs M, et al : Overnight decrease in hematocrit after nasal CPAP treatment in patients with OSA. Chest $97: 729 \sim 730,1990$.

18) Weidmann $P$, Hasler L, Gnadinger MP, et al : Blood levels and renal effects of atrial natriuretic peptide in normal man. J Clin Invest $77: 734 \sim 742,1986$.
19）平田恭信：心房性ナトリウム利尿ペプチド，循 環器 $22: 465 \sim 470,1987$.

20）中川基哉, 島本和明, 飯村 攻 : 心房性ナトリ ウム利尿ペプチドと高血圧. 臨床医 $17: 2144$ 〜2147, 1991.

21）中村元行, 荒川直志, 平盛勝彦: 心房性ナトリ ウム利尿因子と循環器疾患. 呼と循 $39: 971$ 978, 1991.

22) Krieger J, Laks L, Wilcox I, et al : Atrial natriuretic peptide release during sleep in patients with obstructive apnea before and during teatment with nasal continuous positive airway pressure. Clin Sci 77 : 407 411, 1989.

23）赤柴恒人, 吉沢孝之, 堀江孝至 : Nasal CPAP. 呼と循 $39: 123 \sim 129,1991$.

24）羽田憲彦, 高橋典明, 大嶋 康, 他 : Nasal CPAP 療法が著効を示した肺高血圧を伴ら閉塞 型睡眠時無呼吸症候群の 1 例. 日気食会報 41 : 315 320, 1990.

25) Hedner J, Ejnell H, Sellgren J, et al : Is high and fluctuating muscle nerve sympathetic activity in the sleep apnea syndrome of pathogenetic importance for the developmentof hypertension? J Hypertansion 6 suppl 4 : 529 531, 1988.

26) Goodall $M$ and Alton $H$ : Urinary excretion of adrenaline metabolites in man during intervals of 2 minutes, 5 minutes and 10 minutes after intravenous injection of adrenaline. Biochem Pharmacol $14:$ 1595 1604, 1965.

27）田代哲男, 清水徹男, 飯島壽佐美, 他 : 睡眠時 無呼吸症候群に拈ける高血圧症の発症機序 一 とくに交感神経系の役割について一. 神経進歩 $34: 827 \sim 842,1990$.

28) Follenius M, Krieger J, Krauth MO, et al : Obstructive sleep apnea treatment ; peripheral and central effects on plasma renin activity and aldosterone. Sleep $14: 211 \sim 217,1991$.

29) Mayer J and Peter JH : First experience with Cilazapril in the treatment of sleep apnearelated hypertension. Drugs 41 Suppl $1: 37 \sim$ 47, 1991.

30）国枝武義：睡眠時無呼吸症 一循環系への影響 一. JOHNS $7:$ 905 912, 1991. 
31) Bradley TD, Rutherford R, Grossman F, et al : Role of daytime hypoxemia in the pathogenesis of right heart failure in the obstructive sleep apnea syndrome. Am Rev Respir Dis 131 : 835 839, 1985.

32) Bradley TD, Rutherford R, Lue F, et al : Role of diffuse airway obstruction in the hypercapnea of obstructive sleep apnea. Am Rev Respir Dis 134 : 920 924, 1986.

33）石田達也：上気道狭窄と中咽頭圧検査法.耳鼻 臨床 $78 ： 411 \sim 432,1985$.

34）武市佳代子：小児における睡眠時呼吸障害の検 討一扁桃肥大児を中心として一. 日耳鼻 91 : $88 \sim 100,1988$.

35）戸川 清, 宮崎聡一郎, 山川浩治 : 睡眠時無呼 吸症候群の検査と診断. 耳喉 $61: 681 \sim 687$, 1989.

36）山川浩治, 宮崎聡一郎, 戸川 清 : 睡眠時無呼 吸症候群の病態診断. 耳鼻臨床 $84: 870 \sim 874$, 1991.

37) Tolle FA, Judy WV, Yu P, et al : Reduced stroke volume related to pleural pressure in obstructive sleep apnea. J Appl Physiol 55 : 1718 1724, 1983.

38) Ringler J, Basner RC, Shannon R, et al : Hypoxemia alone does not explain blood pressure elevations after obstructive apneas. J Appl Physiol 69 : 2143 2148, 1990.

39）石田達也，木原浩文，山口幹夫，他 : 閉塞型睡 眠時無呼吸発作時の血圧変動.耳鼻臨床 82： 1285 1291, 1989

40) Tilkian AG, Guillemiault C, Schroeder JS, et al : Sleep-induced apnea syndrome; prevalence of cardiac arrhythmias and their reversal after tracheostomy. Am J Med $63: 348 \sim 358,1977$.

41) Miller WP : Cardiac arrhythmias and conduction disturbances in the sleep apnea syndrome. Am J Med $73:$ 317 321, 1982.

42) Guilleminault C, Connolly SJ and Winkle RA : Cardiac arrhythmia and conduction disturbances during sleep in 400 patients with sleep apnea syndrome. Am J Cardiol 52 : 490 494, 1983.

43) Shepard JW, Garrison MW, Grither DA, et al : Relationship of ventricular ectopy to oxyhemoglobin desaturation in patients with obstructive sleep apnea. Chest $88: 335 \sim 340$, 1985.

44) Bayes de Luna A, Coumel P and Leclercq JF : Ambulatory sudden cardiac death : Mechanisms of production of fetal arrhythmia on the basis of data from 157 cases. Am Heart J $117: 151 \sim 159,1989$.

45）田辺晃久：不整脈之突然死. 日医師会誌 106 : $1364 \sim 1368,1991$.

46）野田明子, 岡田 保, 安間文彦, 他: 睡眠時無 呼吸症候群の心拍数変動 一特に換気再開に伴 ら頻脈についての検討一. 呼と循 38:1097〜 1105, 1990.

47) Zwillich C, Delvin T, White D, et al : Bradycardia during sleep apnea; characteristics and mechanism. J Clin Invest 69 : 1286 1292, 1982.

$$
\left(\begin{array}{l}
\text { 別刷請求先 : 石田達也 } \\
\text { †770 徳島市蔵本町2-50-1 } \\
\text { 徳島大学医学部耳鼻咽喉科学教室 }
\end{array}\right)
$$

